\title{
Inclusive Mobility or Inclusive Accessibility? A European Perspective*
}

\author{
¿Movilidad inclusiva o accesibilidad inclusiva? \\ Una perspectiva europea
}

\author{
Caroline Gallez \\ Université Paris-Est, LVMT-IFSTTAR \\ caroline.gallez@ifsttar.fr \\ Benjamin Motte-Baumvol \\ Université Bourgogne Franche Comté, UMR 6049 THEMA, CNRS \\ benjamin.motte@u-bourgogne.fr
}

doi: http://dx.doi.org/10.18543/ced-56-2017pp79-104

Contents: I. Introduction.-II. Mobility and social inclusion on the EU agenda.-III. Mobility and social exclusion: changes relating to the reformulation of the social question.-IV. Right to transport and access to resources in French and British policies.-V. Inequalities in mobility: a European overview.-VI. The ambiguities of a right to mobility for all.-VII. From the right to mobility to universal access to the city?VIII. Conclusion. -IX. Bibliography.

\footnotetext{
Abstract: "Inclusive mobility" is part of a set of political priorities defined by several European countries to refer to the social dimension of transport or daily mobility policies. More generally, "inclusiveness" refers to social cohesion, which has been one of the declared objectives of the European Union since the beginning of the 2000s. As a way to facilitate access to opportunities, individual mobility is currently considered as a necessary prerequisite for people's participation in social activities. In contrast, immobility or "lack of mobility" would be a risk factor for social exclusion. However, due to the ambiguity of mobility - which can be considered either as an essential resource or as a cost; as a basic right or as an injunction to be "mobile"-political objectives of inclusive mobility can mask some contradictions. In this article, we focus on different issues related to inclusive mobility in Europe. First, we discuss the way in which social aspects of transport and mobility are taken into account in the European and national political agendas. Then, we give a picture of social inequalities regarding daily mobility in
}

* Recibido el 9 de enero de 2017, aceptado el 6 de marzo de 2017. 
different European countries. Finally, we discuss the opportunity to change political priorities from inclusive mobility to inclusive accessibility.

Keywords: mobility, accessibility, social inclusion, public policy, Europe.

Resumen: "La movilidad inclusiva" es parte de las prioridades politicas definidas por numerosos países europeos para referirse a la dimensión social del transporte o las políticas de movilidad cotidiana. De forma general, la inclusión se refiere a la cohesión social, que ha sido uno de los objetivos declarados de la Unión Europea desde el inicio de los años 2000. Como mecanismo para facilitar el acceso a las oportunidades (empleo, comercio, servicios, etc.), la movilidad individual es actualmente considerada un prerrequisito necesario para la participación de las personas en las actividades sociales. En contraste, la inmovilidad o "ausencia de movilidad" sería un factor de exclusión social. Sin embargo, en razón de la ambigüedad de la movilidad, que puede considerarse un recurso esencial (facilitador de acceso a oportunidades en el contexto de una dispersión mayor de las actividades) o un coste (monetario, medioambiental, físico); un derecho básico o un precepto político para movilidad (los objetivos políticos de la movilidad pueden esconder algunas contradicciones). Este artículo se concentra en diferentes problemáticas en relación a la movilidad inclusiva en Europa. Para empezar, presentamos cómo el lema de la "movilidad inclusiva" es utilizado en los documentos oficiales de la Comisión Europea. Posteriormente, se analiza cómo la cuestión de la movilidad inclusiva ha emergido en Francia y en el Reino Unido, en relación a la generalización del problema de la exclusión social. Se completará esta visión de políticas públicas ofreciendo un panorama de las desigualdades sociales en relación a la movilidad cotidiana en diferentes países europeos. Finalmente, se argumenta la necesidad de evolucionar desde una prioridad política de la movilidad inclusiva hacia la accesibilidad inclusiva, considerando que las políticas de movilidad, como elemento favorecedor de la dispersión de las actividades, pueden incrementar la presión sobre los grupos sociales desfavorecidos para ser móviles.

Palabras clave: movilidad, accesibilidad, desigualdades sociales, inclusión social, Europa, Francia, Reino Unido.

\section{Introduction}

No one would argue against the centrality of spatial mobility in our contemporary ways of life. According to John Urry ${ }^{1}$, mobility in various forms - physical travel, movements of objects, communications, IT connections or imaginary journeys - is the medium for a growing

1 John Urry, Sociology Beyond Societies (London: Routledge, 2000); John Urry, Mobilities (Cambridge: Polity Press, 2007). 
number of social interactions that are constructed "at-a-distance", in consequence of the spatial dispersal of places of residence and work. While the development of transport networks and information and communication technologies has for several decades reinforced such spatial or virtual mobilities, these concomitant developments cannot be reduced to a form of technical determinism. As Jean Rémy ${ }^{2}$ noted, "if mobility gains momentum, it is not only because it is technically possible, but also because it is socially desired".

In particular, the ability of people to move in geographical space is generally presented as an essential condition of social integration, and immobility, or difficulty in moving easily, whether caused by physical disabilities or a lack of material resources, as a handicap that public policies should seek to remedy. From this perspective, the guarantee of access to mobility for all, otherwise called the "right to mobility", constitutes one of the conditions for the participation of all individuals in society, i.e. for an inclusive society. In practice, however, the implementation of this right to mobility poses problems at several levels.

On the one hand, the positive valuation of mobility characteristic of contemporary Western societies does not apply equally to all social groups. The controversies surrounding the free movement of workers during the debates on the enlargement of the European Union in 2005 are an illustration of the often violent reactions against the universal application of this principle, embedded though it is in the origins of European law. So the increasing mobility of European citizens, which bears witness to the progress of European construction, also elicits controversies, strong anxieties and debates about the boundaries and borders of the European Union ${ }^{3}$. Although frequently associated with mobility, especially since the revolutionary period and the ascendancy of the philosophy of liberalism, mobility is never a universal capacity ${ }^{4}$. It is socially constructed and produced, regulated, normed, controlled, within a context of asymmetric power relations ${ }^{5}$. Implementing a social right to mobility entails, in particular, the definition and application of technical mechanisms, instruments of regulation, laws, tariffs and border categories, which allow or facilitate the movement of some

2 Jean Rémy, «Mobilités et ancrages: vers une autre définition de la ville», in Mobilités et ancrages: vers un nouveau mode de spatialisation?, ed. Monique Hirschhorn and JeanMichel Berthelot (Paris: L'Harmattan, 1996), 135-153.

3 Anne-Marie Fortier, «The Politics of Scaling, Timing and Embodying: Rethinking the

'New Europe'», Mobilities 1, 3 (2006): 313-331.

${ }^{4}$ Céleste Langan, «Mobility Disability», Public Culture 13, 3 (2001): 459-484.

5 Tim Cresswell, «The Right to Mobility: The Production of Mobility in the Courtroom», Antipodes 38, 4 (2006): 735-754. 
to the detriment of others, in implicit opposition to the ideal of a universal and individual right to mobility.

On the other hand, the increase in the movement of people and goods generates numerous problems and collective social, economic and environmental costs. The growth of motorised traffic, in particular automobile traffic, is responsible for the emission of a range of pollutants and greenhouse gases, as well for increases in noise, road safety problems and fossil fuel consumption. Atmospheric and noise pollution are of particular concern in cities, where health risks rise with rates of exposure. On the other hand, the development of transport networks and the use of the car has encouraged periurbanisation, in a twofold trend towards the decoupling of residential location and employment from the central cores, and the "bulking up" of villages or peripheral towns within the magnetic field of central employment zones. Since the 1990s, the sustainability of this urban growth, in terms of collective infrastructure costs, swallowing of natural areas, energy expenditure, health risks, deterioration in quality of life, and also automobile dependency ${ }^{6}$, has increasingly been challenged. Ultimately, access to mobility and the consequences of increased mobility are highly discriminatory between social groups: moving has a cost, which absorbs a large proportion of household budgets for the most modest or precarious population categories; traffic also exposes some of the most deprived social groups to significant harm from noise, pollution, and deterioration in living conditions; finally, because of increasingly strained conditions in the labour and housing markets, vulnerable populations are the most dependent on mobility, which they use as a way of adjusting to the other constraints.

Issues relating to the regulation of day-to-day mobility ${ }^{7}$ illustrate these contradictions pertaining to the social utility and costs of mobility. The apparent consensus around the concept of sustainable mobility, widely used in political, technical and media vocabulary, masks sharp political tensions around the objectives and means of regulating day-to-day travel, echoing the broader controversy on the role of mobility and its impact on social and urban dynamics. These tensions are substantially reflected in scientific controversies. Several authors contest the dominance of the environmental dimension in the orientation of public policies, arguing the potentially negative consequences for social inequality of regulation that would begin

${ }^{6}$ Gabriel Dupuy, La dépendance automobile. Symptômes, analyses, diagnostic, traitement (Paris: Anthropos, 1999).

${ }^{7}$ Understood here in its usual sense of all the trips made by individuals in order to carry out their habitual activities. 
by impacting the most vulnerable populations ${ }^{8}$. Quite apart from their content, these controversies reflect the redefinition of a problem of public action and testing in a sector - that of transport - which has long been characterised by the dominance of technical and functional perspectives ${ }^{9}$.

How do these different points of view concerning the social aspects of mobility find expression in Europe today? What do we learn from the observations of inequalities in (or in response to) mobility in different European countries? In this article, we propose to analyse first of all the way in which public policies reflect ways of thinking and acting upon social inequalities in relation to everyday mobility. To do this, we situate ourselves at different geographical scales and at different time periods. We begin by analysing how these questions came to be part of the agenda of the European Commission. Then we show how the theme of "inclusive mobility" emerged in France, then in the United Kingdom, in relation to the generalisation of the problem of social exclusion. We then highlight the differences in the way the two countries have tackled this theme, reflecting their embeddedness in distinct national political and social traditions. We complement this overview of public policies by presenting the social inequalities in mobility in different European countries. Drawing on this comparison between the ways in which the social question is translated into transport and mobility policies and the measurements of social inequalities in mobility, we then turn to the ambiguities in the right to mobility, between access to mobility for all and the obligation of mobility placed on the most disadvantaged population groups. Finally, we conclude by exploring the notion of accessibility as an approach to equity in access to resources.

\section{Mobility and social inclusion on the EU agenda}

Adopted in 2007, the last Green Paper on urban mobility ("Towards a new culture for urban mobility"), which aims to "set a new agenda for urban mobility", states that this agenda respects the responsibilities of local, regional and national levels in this sphere. Starting from the position that all European cities face similar problems, which have repercussions on a continental scale, the authors affirm the need for cooperation and

8 Jean-Pierre Orfeuil, Transports, pauvreté, exclusions. Pouvoir bouger pour s'en sortir (Paris: L'Aube, 2004); Julian Hine, «Travel demand management and social exclusion», Mobilities 2, 1 (2007): 109-120.

9 Caroline Gallez, La mobilité quotidienne en politique. Des manières de voir et d'agir, Mémoire d'habilitation à diriger des recherches (Marne-la-Vallée: Université Paris Est, 2015). 
coordination at European level, stressing that "the European Union must play a leading role in order to focus attention on this issue". However, this positioning of the European Commission on strategic issues is not enough to convince local actors of its legitimacy in intervening in the sphere of urban mobility. In his comments to the French Senate on the Green Paper, French Senator Roland Ries, in charge of urban mobility, stressed the difference between global issues and legitimacy: "Problems that are common to cities in Europe should not be confused with community prerogatives. The question is not whether the topic is important to Europeans, but whether Europe is best placed to act. Neither in Europe, nor in the Member States, is mediation sufficient to establish legitimacy."10

It is therefore through its major fields of intervention, in particular its key role in supporting economic growth in the European zone and taking account of environmental issues, that the Community is attempting to drive moves towards a common roadmap for local urban mobility policies. More specifically, it is in the choices between economic interests and limiting environmental and health damage that the priorities for community action have been set since the early 1990s, when environmental concerns made urban transport a priority target.

The term "sustainable mobility" appears in the official vocabulary of the European Commission in 1992, in the Green Paper on the impacts of transport on the environment ${ }^{11}$. For the first time, reducing motorised traffic is considered necessary, both to tackle congestion problems on road infrastructures, and in response to air quality issues. On the one hand, the pertinence of the transport supply paradigm, the "predict and provide" principle, was beginning to be contested in numerous scientific works (e.g. Goodwin et al. ${ }^{12}$, Banister ${ }^{13}$ ), which showed that increasing road capacity does not reduce traffic congestion. On the other hand, the global increase

10 Communication by Mr Roland Ries relating to the Green Paper on urban transport, Senate (27 November 2007). [Online]: https://www.senat.fr/ue/pac/E3647.html, accessed 28 September 2016.

11 Jade Bourdages and Eric Champagne, «Penser la mobilité durable au-delà de la planification traditionnelle du transport», VertigO - la revue en ligne des sciences de l'environnement 11713 (2012), http://vertigo.revues.org/11713; "This green paper provides an assessment of the overall impact of transport on the environment and presents a common strategy for 'sustainable mobility' which should enable transport to fulfil its economic and social role while containing harmful effects on the environment": CEE, Green paper on The Impact of Transport on the Environment. A Community strategy for "sustainable mobility", $\operatorname{COM}(92) 46$ final, (1992): 5.

12 Phil Goodwin et al., Transport: the new realism, Report 624, Transport Studies Unit (Oxford: University of Oxford, 1991).

13 David Banister, «Reducing the Need to Travel through Planning», Town Planning Review 65, 4 (1994): 349-354. 
in mobility associated with growing economic activity was threatening to nullify efforts made since the early 1970s to reduce pollutant emission rates through the implementation of European regulations on new vehicles. As managing mobility demand came onto the political agenda, this moment seems to mark the end of a widely shared international consensus that improvements in transport supply and increased mobility - as factors of economic growth and social progress - were a priori desirable ${ }^{14}$.

Less than a decade later, however, the reaffirmation of the priority placed on European economic growth by the Lisbon Strategy challenged this objective of regulating mobility and transport, at least at national and international levels. The financial crisis of the late 2000s would only strengthen the primacy of economic objectives and thereby of transport system performance. The major role of transport and mobility in stimulating competitiveness and economic growth is highlighted in the 2011 White Paper: "Transport is fundamental to our economy and society. Mobility is vital for the internal market and for the quality of life of citizens as they enjoy their freedom to travel. Transport enables economic growth and job creation: it must be sustainable in the light of the new challenges we face" 15 . Managing mobility demand to reduce environmental impact or improve congestion problems was no longer on the agenda: "Curbing mobility is not an option". The challenge was to solve energy and environmental problems without sacrificing its effectiveness or compromising mobility ${ }^{16}$. Various solutions were envisaged, based around technological advances (electric vehicles, autonomous vehicles, clean engines), massive investment in the development of non-road infrastructure and, in urban areas, planning policies that foster reductions in the need for travel and the use of public transport.

The social aspects of mobility are part of a general policy framework outlined by these broad economic and environmental frameworks.

In the 1992 Green Paper, the social dimension of sustainable mobility is limited to the recognition of the 'social role of transport', in particular in its contribution to the economic and social cohesion of the European Community. It is through more cross-cutting issues that the social orientations of transport policies would gradually become clearer. The concept of social inclusion is introduced formally at the European Council's Lisbon Summit in 2000. It refers to the goal that all European citizens

14 David L. Greene and Michael Wegener, «Sustainable transport», Journal of Transport Geography 5, 3 (1997): 177-190.

15 European Commission, White paper on transport. Roadmap to a single European transport area (Publications Office of the European Union (Luxembourg: 2011): 3 .

${ }_{16}$ European Commission, White paper... 5. 
should share in the benefits of economic integration and economic growth ${ }^{17}$. In the 2007 Green Paper, the social dimension is incorporated in the form of improvements in access to mobility and the matching of services to people's needs. The quality and efficiency of public transport modes, the diversity of mobility services, improved information for travellers, the use of new technologies to develop teleworking or to optimise traffic regulation, the development of shared uses of the car, are all ways to satisfy mobility needs while reducing environmental impacts. In addition to these goals of improving the supply and operating conditions of mobility services, a further objective is the accessibility of the urban transport system to people with specific needs, such as those with reduced mobility or disabilities, the elderly, families with young children, and young children themselves. The financial crisis of 2008 prompted a partial revision of the objectives set out in the Lisbon Strategy. The new "Europe 2020" roadmap adopted in 2010 ("A strategy for smart, sustainable and inclusive growth"), contains the term inclusive growth, referring to the aims of fighting poverty and social exclusion. In a context where most European countries were focused on cutting fiscal deficits, restoring growth and increasing employment, the dominant problems were those of access to employment and primary goods such as health. In this respect, individual access to a car was one of the nine criteria used in measuring material deprivation and assessing the risk of social exclusion ${ }^{18}$.

Institutional frameworks to support the action of local authorities in favor of inclusive mobility are defined by the different Members State. The European Commission ensures legal compliance of these national frameworks regarding the rights of passengers, especially the right to travel of persons with reduced mobility and the public service obligations. At a more incentive level, the European Commission is initiating and funding research and experimentation programs, focused on diverse issues of inclusive mobility, such as universal accessibility systems for public transport or transport needs for an ageing society.

To sum up, the inclusion of the social aspects of urban mobility in European Community documents fits into a doubly restricted space: from the organisational point of view, responsibility for urban transport

17 Eric Marlier et al., «Developing and learning from measures of social inclusion in the European Union», in Counting the poor: New thinking about European poverty measures and lessons for the United States, ed. Douglas J. Besharov, D.J. and Couch, Kenneth A. (Oxford: Oxford University Press, 2012): 299-338.

18 Bernard Maître, Brian Nolan and Christopher T. Whelan, «L'indicateur EU2020 de suivi de la pauvreté et de l'exclusion : une analyse critique», Économie et Statistique 469-470 (2014): 147-167. 
is primarily the responsibility of local and national authorities; at a more substantive level, the Community's primary transport priorities - recognised as such by its members - are economic development and environmental protection, thereby limiting the attention paid to the social dimension. Consequently, the social dimension of the right to mobility at European level is essentially present in the transport aspect of social policies, in addition to the policies implemented by each of the Member States.

\section{Mobility and social exclusion: changes relating to the reformulation of the social question}

This European analytical perspective only partially accounts for developments in national political debates around the relations between poverty and social exclusion on the one hand, and transport and mobility on the other.

In Europe, as in the United States, periods of social crisis were fertile ground for exploration of the link between poverty and unemployment and access to transport ${ }^{19}$. By the end of the 1950 s, protest movements were emerging in various American cities against the large-scale demolition of housing in poor neighbourhoods, environmental degradation and loss of quality of life caused by the construction of urban expressways. In some cases these currents were connected with the African-American struggle for political emancipation and the civil rights movement ${ }^{20}$. Convergence between social, racial and transport issues was also apparent in protests against discrimination in access to public transport, due to segregation, as well as in access to employment, schools and urban resources for the poor, mainly black and Hispanic populations. The federal government's recognition of these problems, following the urban riots that broke out in several American cities in the 1960s, resulted in the creation in 1964 of a federal Urban Mass Transportation Administration (UMTA) responsible for working on the development of urban public transport.

The social priority of improving urban public transport also came to the fore in several European countries in the 1960s and 1970s. The question of social inequalities in access to mobility has arisen in a context where public authorities were becoming aware of limits to the democratisation of the

19 Thomas W. Sanchez, «Poverty, policy, and public transportation», Transportation Research A 42 (2008): 833-841.

${ }^{20}$ Raymond A. Mohl, «Stop the road: Freeway revolts in American cities», Journal of Urban History 30, 5 (2004): 674-706. 
automobile and to the spread of individual car ownership. The first limiting factor was the congestion of the main arteries leading into city centres, a trend flagged in traffic models as presenting a potential brake on economic growth. In the biggest conurbations, developing efficient public transport provision emerged as an alternative to the influx of cars into the city centre. The second limiting factor was the inaccessibility of the car to a wide range of population categories, for reasons of age, disability or economic incapacity. The subsequent development of public transport contributed to the provision of a "social" transport service for people without cars, described at the time as "captive users". Social pricing measures, which varied greatly from one conurbation to another, were another instrument in the toolbox deployed in the transport sector to ensure access to mobility.

In the 1990s, the social question began to be formulated differently, prompting a change in the way mobility-related inequality issues were discussed. The concept of social exclusion began to feature in the political lexicon. Originating in France at the end of the 1970s, exclusion was a notion first used by voluntary sector representatives to challenge the public authorities over the emergence of new forms of inequality ${ }^{21}$. It then slowly spread into the public arena, notably as a result of numerous studies conducted in the 1990s on trends in the social question, which picked up the concept and helped to give its scientific legitimacy ${ }^{22}$. Although the definition and even the relevance of this term were disputed, most authors agreed that the spread of the notion of social exclusion reflected a conceptual change in the way of defining, studying, measuring or assessing the causes and effects of phenomena or social conditions previously designated in terms of poverty, deprivation or marginality ${ }^{23}$. Whereas poverty refers to a lack of resources or of access to material well-being, social exclusion relates to a process in which individuals are totally or partially deprived of their capacity to participate in the society in which they live. In this approach, people's ability to access a number of resources (including education, work, health, leisure, etc.) is a prerequisite of their participation in society ${ }^{24}$. One of the central aspects of this approach to

${ }^{21}$ Emmanuel Didier, «De 1'“exclusion” à l'exclusion», Politix 9, 34 (1996): 5-27.

${ }^{22}$ Robert Castel, Les métamorphoses de la question sociale. Une chronique du salariat (Paris: Gallimard, 1999) ; Pierre Rosanvallon, La nouvelle question sociale. Repenser l'Etat providence (Paris: Seuil, 1995) ; Serge Paugam, L'exclusion. L'état des savoirs (Paris: La Découverte, 1996).

${ }^{23}$ Philine Gaffron, Julian Hine and Falconer Mitchell, The role of transport on social exclusion in urban Scotland, Literature Review, Transport Research Unit (Edinburgh: Napier University, 2001).

${ }^{24}$ Andrew Church, Martin Frost and Karen Sullivan, «Transport and social exclusion in London», Transport Policy 7 (2000): 195-205. 
social problems was the new emphasis on the spatial dimension of social inequality. In particular, access to resources was seen as being conditioned by the place of residence and the possibility of travelling, and therefore by access to a means of transport.

Scientifically as well as politically, the 1990s were a time of growing hybridisation between the themes of social exclusion and mobility, which had hitherto been treated independently. Depending on the cultures and social and political contexts within which it took place, this shift in the social question gave rise to the expression of different public problems and political solutions, as illustrated by the cases of France and Great Britain.

\section{Right to transport and access to resources in French and British policies}

In France, the question of the "right to transport" was spelled out at the beginning of the 1980s, in the 1982 Domestic Transport Guidelines Act (Loi d'orientation sur les transports intérieurs, LOTI), which was one of the first of the decentralisation laws. It specified that the implementation of this Act, which concerned the possibility for users to "travel on reasonable terms of access, quality and price, as well as of cost to the community" 25 , was based in particular on "the use of a publicly available means of transport". The law bore the stamp of the political context in which it was passed: the arrival of the left in power and a transport minister, the communist Charles Fiterman, particularly committed to these issues. It also represented a continuation of national policy, introduced in the early 1970s, for the rehabilitation of urban public transport, which resulted in the introduction of dedicated funding for urban transport networks, levied by the Urban Transport Organising Authorities (Autorités organisatrices des transports urbains, AOTU). LOTI also provided for the implementation of special measures in favour of people with reduced mobility or from disadvantaged social categories, though without any legal obligation. Nonetheless, the increase in unemployment and job insecurity in the 1980s and 1990s led a growing number of public transport networks to implement social pricing policies ${ }^{26}$. However, it was not until the SRU Act (Loi relative à la Solidarité et au Renouvellement Urbains) of 13 December 2000 that such social pricing became compulsory, with the "implementation of the right to

${ }^{25}$ Loi n ${ }^{\circ} 82-1153$ d'orientation des transports intérieurs, Titre Ier, article 2.

26 Dominique Mignot, Mobilité et grande pauvreté (Paris: Rapport final pour le ministère de l'Equipement, des Transports et du Logement et pour l'Union des Transporteurs Publics, 2011). 
transport", whereas these allowances had been an obligation for the other urban utilities since the $1980 \mathrm{~s}^{27}$.

Outside the transport sector, access to mobility was becoming a central issue for other urban policies, especially in the social sphere. With its focus on intervention in certain so-called "sensitive" neighbourhoods, the "Politique de la Ville" (State's urban renewal policy) typified the spatialisation of social problems associated with the issue of social exclusion. Following the 1991 "Transport and Social Exclusion" report by the National Transport Council, which highlighted inequalities in access to priority areas, the connection of deprived neighbourhoods became a key objective of the "contrats de ville" ("town contracts") signed by the local elected representatives ${ }^{28}$. Achieving this objective required the upgrading of access roads, but also improvements in public transport provision to these areas ${ }^{29}$. Locally, elected representatives in several large urban centres where new public transport lines, in particular tramlines, were being introduced, chose to prioritise provision to social housing zones. More generally, the issue of access to mobility was becoming a priority in the return to work policies developed in France, as in other European countries, during the 2000s, with employability being assessed, among other factors, in terms of access to mobility ${ }^{30}$. The role of the actors of social policies and employment policies was central to the implementation of a range of transport subsidies ${ }^{31}$. Many community organisations addressed this issue by proposing innovative solutions for access to private cars (social driving schools, community garages) or mobility assistance for people returning to work (e.g. actions implemented by "Wimoov", an association which helps job seekers to find mobility solutions and the "Inclusive mobility laboratory" created by Wimoov and the oil company Total ${ }^{32}$ ).

Recognition of the link between social exclusion and mobility came later in the United Kingdom. Compared to France, where the issue of access to resources was mainly expressed in terms of mobility problems and solutions, in the UK the ambition was much more wide-ranging.

${ }^{27}$ Cécile Féré, Concilier accès à la mobilité et mobilité durable. La prise en compte des inégalités d'accès à la mobilité dans les politiques urbaines de l'agglomération lyonnaise, Thèse de doctorat en géographie, aménagement et urbanisme (Lyon: Université de Lyon II, 2011).

28 Sylvie Fol, La mobilité des pauvres (Paris: Belin, 2009).

${ }^{29}$ Christian Harzo, Mobilité des populations en difficultés: connaissance des besoins et réponses nouvelles, document de synthèse (Paris: Report DIV et Ministère de l'Emploi et de la Solidarité,1998).

${ }^{30} \mathrm{Fol}$, La mobilité des pauvres....

31 Mignot, Mobilité et grande pauvreté... ; Eric Le Breton, Bouger pour s'en sortir. Mobilité quotidienne et intégration sociale (Paris: Armand Colin, 2005).

${ }^{32}$ Cf. http://www.wimoov.org; http://www.mobiliteinclusive.com 
In 1997, Tony Blair's Labour government made the fight against social exclusion one of its priorities. An intergovernmental entity, the "Social Exclusion Unit" (SEU), was established to fund studies and research in order to establish diagnoses, to identify the determining factors in the exclusionary process, and to provide support for the implementation of solutions. As early as 1998, the White Paper on Transport, entitled "A new deal for transport: better for everyone", describes the links between transport and social exclusion ${ }^{33}$. The priority was to promote the implementation of an integrated transport policy, integrated not only in the sense of including the different modes of transport, the environment, transport and land use, but also education, health and employment policies, "so that transport helps to make a fair, more inclusive policy".

The SEU's 2003 annual report "Making the Connections: Final report on Transport and Social exclusion" identifies the lack of access to certain opportunities (employment, education, health) as a factor of social exclusion $^{34}$. While transport problems play a big role in the SEU report, it recognises that access to urban services is not only a question of transport, but also depends on how certain key activities are located and made available to people: "Solving accessibility problems may be about transport but also about locating and delivering key activities in ways that help people reach them" 35 . At the same time, the British government established the principles of accessibility planning, which advocated better integration between transport policies and the location of activities and services, with the aim of "creating a process that is more transparent, more integrated and more equitable in decisions on transport and urban planning" 36 .

The creation of a unit like the SEU, with an interdepartmental role, was evidence of the desire to broaden the issue of access to resources beyond the transport sector alone. In practice, the implementation of accessibility planning was hampered by segmentations between the priorities and scope of action of public departments. Accessibility indicators, which primarily depended in their form on the objectives sought, were sometimes inappropriately applied ${ }^{37}$. Nonetheless, as Halden ${ }^{38}$ points out, one of the major contributions of accessibility indicators was to open up the range of

${ }^{33}$ Fol, La mobilité des pauvres...

34 Social Exclusion Unit (SEU), Making the Connections: Final report on Transport and social exclusion, (London: Report SEU, 2003).

35 Social Exclusion Unit (SEU), Making the...

${ }^{36}$ Karen Lucas, «Providing transport for social inclusion within a framework for environmental justice in the UK», Transportation Research Part A 40 (2006): 801-809.

37 Derek Halden, «The use and abuse of accessibility measures in UK passenger transport planning», Research in Transportation Business and Management 2 (2011): 12-19.

38 Halden, «The use and abuse... 
possible solutions for managing transport policies and to adapt them to the needs of citizens and users.

\section{Inequalities in mobility: a European overview}

Measuring inequalities in access to modes of transport or in travel practices provides another perspective on the issue of relations between mobility and equity in access to urban ressources. A quick overview of the data available in different European countries shows the difficulty of interpreting differences in mobility.

Access to mobility differs between social groups and particularly between income levels ${ }^{39}$. Financial poverty is not, however, the only social factor that impacts on inequalities in mobility. Other notable dimensions are gender inequality, the effects of racialisation, situations of physical, sensory or cognitive disability, or prejudices relating to age or origin. Economic inequality is overlaid and amplified by other social factors. Regardless of any accumulation of social disadvantages, scarcity of economic resources has a specific effect on day-to-day mobility. So poor households make shorter and less frequent trips. Their mobility deficit is primarily attributable to lower access to the car, in terms of both ownership and use.

Car ownership and use are widespread in Europe, but they are unevenly distributed, particularly by income ${ }^{40}$. In France, the difference in household motorisation between the first quartile and the other three quartiles is 10 points $(75 \% \text { against } 85 \%)^{41}$. Besides the level of motorisation, income-based inequalities also affect the type and age of the $\mathrm{car}^{42}$, the type of insurance ${ }^{43}$ and

39 Lourdes Diaz Olvera, Dominique Mignot and Christelle Paulo, «Daily mobility and inequality: the situation of the poor», Built Environment 30 (2004): 153-160; Sarah Wixey et al., Measuring accessibility as experienced by different socially disadvantaged groups. Report, Transport Studies Group, University of Westminster (London: 2005).

40 Joyce Dargay and Mark Hanly, «Volatility of car ownership, commuting mode and time in the UK», Transportation Research Part A 41 (2007): 934-948; Genevieve Giuliano and Joyce Dargay, «Car ownership, travel and land use: a comparison of the US and Great Britain», Transportation Research Part A 40 (2006): 106-124.

${ }^{41}$ Roger Collet, Jean-Loup Madre and Laurent Hivert, «Diffusion de l'automobile en France : vers quels plafonds pour la motorisation et l'usage?», Economie et statistiques 457458 (2013): 1-17.

42 Chandra R. Bhat, Sudeshna Sen and Naveen Eluru, «The impact of demographics, built environment attributes, vehicle characteristics, and gasoline prices on household vehicle holdings and use», Transportation Research Part B 43 (2009): 1-18.

43 John Taylor et al., The travel choices and needs of low income households-the role of the car, Report, National Centre For Social Research (London: 2008). 
maintenance and repair ${ }^{44}$. Lower-income individuals then turn to alternative modes to the car: walking, public transport and the bicycle. For example, in the Netherlands, the poorest $10 \%$ of the population make almost $30 \%$ of their trips by bicycle as compared with just over $20 \%$ for the wealthiest $10 \%{ }^{45}$.

However, individuals who do not own cars are not excluded from car use. In France, a third of non-motorised adults make one car trip during a working week, either as passenger or driver ${ }^{46}$. In Germany, Scheiner ${ }^{47}$ shows that individuals living in households without cars average about 12 kilometres and one car trip per week. Dargay and Hanly ${ }^{48}$ show that UK households can alternate between motorisation and non-motorisation. From one year to the next, about $6 \%$ of households switch from car ownership to non car ownership, while the same number switch the other way.

Even when more or less continuously motorised, poor households make extremely moderate use of the car $^{49}$. In France, adults in the first income quartile travel an average of 6,500 kilometres a year by car compared with more than 8,000 for adults in the second quartile and more than 10,000 for adults in the last quartile ${ }^{50}$. In Britain, motorised households in the top quintile drive more than three times further per year than those in the bottom quintile ${ }^{51}$. Low-income motorised households also differ in their avoidance of road tolls or parking charges ${ }^{52}$, with the result that they made longer and more difficult journeys.

Beyond the issues of car ownership, low-income individuals can be observed to spend much more time in local areas. In Britain, the ratio between the distances travelled by the top and bottom income quintiles is more than 2 (respectively 4.6 and 9.7 miles). Low-income households tend to limit their movements, including work-related travel, and generally

${ }^{44}$ Laurent Hivert, Le parc automobile des ménages, étude en fin d'année 1999 à partir de la source "Parc Auto" SOFRES, Report (Arcueil: INRETS, 2001).

${ }^{45}$ Karel Martens, «Role of the bicycle in the limitation of transport poverty in the Netherlands», Transportation Research Record: Journal of the Transportation Research Board 2387 (2013): 20-25.

${ }^{46}$ Benjamin Motte-Baumvol, Marie-Hélène Massot and Andrew M. Byrd, «Escaping Car Dependence in the Outer Suburbs of Paris», Urban Studies 47 (2010): 604-619.

47 Joachim Scheiner, «Social inequalities in travel behaviour: trip distances in the context of residential self-selection and lifestyles», Journal of Transport Geography 18 (2010): 679690.

48 Dargay and Hanly, «Volatility of car ownership...

49 Orfeuil, Transports, pauvreté, exclusions...

${ }^{50}$ Richard Grimal, Roger Collet and Jean-Loup Madre, «Is the Stagnation of Individual Car Travel a General Phenomenon in France? A Time-Series Analysis by Zone of Residence and Standard of Living», Transport Reviews 33 (2013): 291-309.

51 Wixey et al., Measuring accessibility as experienced....

52 Taylor et al., The travel choices and needs... 
live closer to their workplace ${ }^{53}$. This is also the case in France, where the working poor are more likely to have jobs in their home community and to commute shorter distances ${ }^{54}$. In addition to distance, the number of trips made with or without the car varies according to income. In France, all things being equal, the differences remain very small, since there is a ratio of 1 to 1.1 between the number of trips made by the top and bottom income quintiles ${ }^{55}$. The gap seems wider in Britain, where households in the top quintile make $35 \%$ more trips than those in the bottom quintile ${ }^{56}$. In fact, under pressure from travel costs, these households tend to minimise the number of trips they make, focusing on access to work, school and basic family needs. They are unable to share in the other resources offered by the city, which, while not essential, are nonetheless useful to social integration ${ }^{57}$. This means that many individuals are limited in their access to activities that are nevertheless essential, such as work ${ }^{58}$, food provisions ${ }^{59}$ or health ${ }^{60}$. Hine and Kamruzzaman ${ }^{61}$ show that individuals without cars or on low incomes make much less use of health services than other groups.

In recent decades, moreover, the conditions of access to urban resources have generally deteriorated. Despite attempts at regulation through public policies, there has been a loosening of the territorial coverage in many facilities. In the UK, for example, the pursuit of "rationalisation" in health facilities has led to the creation of bigger units, which serve a larger population but are less accessible, especially for households without a $\operatorname{car}^{62}$. In France, Caubel ${ }^{63}$ notes how changes in the location of urban activities,

53 Wixey et al., Measuring accessibility as experienced....

${ }^{54}$ Orfeuil, Transports, pauvreté, exclusions....

55 Olvera Diaz et al., «Daily mobility and inequality...

56 Wixey et al., Measuring accessibility as experienced...

57 Sebastián Ureta, «To Move or Not to Move? Social Exclusion, Accessibility and Daily Mobility among the Low-income Population in Santiago de Chile» Mobilities 3 (2008): 269289.

58 Mizuki Kawabata and Qing Shen, «Commuting inequality between cars and public transit: The case of the San Francisco Bay Area, 1990-2000», Urban Studies 44 (2007): 1759-1780.

59 Kelly J. Clifton, «Mobility Strategies and Food Shopping for Low-Income Families", Journal of Planning Education and Research 23 (2004): 402-413.

${ }^{60}$ Samina T. Syed, Ben S. Gerber and Lisa K. Sharp, «Traveling towards disease: Transportation barriers to health care access», Journal of community health 38 (2013): 976993.

61 Julian Hine and Md Kamruzzaman, «Journeys to health services in Great Britain: An analysis of changing travel patterns 1985-2006», Health and place 18 (2012): 274-285.

62 Lucas, «Providing transport for social inclusion...

${ }^{63}$ David Caubel, Politique de transports et accès à la ville pour tous? Une méthode d'évaluation appliquée à l'agglomération lyonnaise, Thèse de doctorat, Université LumièreLyon II, Economie des transports (Lyon: 2006). 
exclusively to the advantage of the better off, have widened the differences in access compared with poorer areas. It is as if the dominant social groups, through their economic or consumer muscle, have contrived to bring activities into their territories to the detriment of the weakest populations ${ }^{64}$. In the case of Britain, according Wixey et al..$^{65}$, about a fifth of car-free households has difficulty accessing a supermarket or doctor.

The limitations and restrictions on the mobility of low-income households are particularly high in peripheral areas where car dependency is more pronounced ${ }^{66}$. Indeed, the disparities in access between central areas and urban peripheries are very large and growing, as demonstrated by studies on cities in France ${ }^{67}$. This trend is of particular concern in that there is a strong propensity for some low-income households to move into the outskirts. In France, rapid growth of low-income populations can be observed in periurban areas, attracted by lower land and housing costs ${ }^{68}$. Living in the outskirts places further pressures on the budgets of lowincome households, in particular because of the cost of car travel ${ }^{69}$.

\section{The ambiguities of a right to mobility for all}

By highlighting the difficulties in measuring inequalities in mobility, these empirical observations cast light on the ambiguities of the right to mobility.

First, it is not easy to interpret inequalities in mobility practices in terms of social inequality. On the one hand, several studies show that some people with limited resources suffer from inadequate access to mobility. Eric Le Breton $^{70}$ uses the term "islanders" to describe individuals who are only able to travel within a very small area around their homes or have to turn down a job because they cannot drive. In reference to these situations, the aim of

${ }^{64}$ Marcel Roncayolo, La ville et ses territoires (Paris: Gallimard, 1990).

65 Wixey et al., Measuring accessibility as experienced...

${ }_{66}$ Motte-Baumvol et al., «Escaping Car Dependence in the...

${ }^{67}$ Benjamin Motte-Baumvol, «L'accès des ménages aux services dans l'espace périurbain francilien», Strates 14, (2008): 149-164 ; Caubel, Politique de transports...

68 Jean Cavailhès and Harris Selod, «Ségrégation sociale et périurbanisation», Inra Sciences Sociales 1-2, (2003): 1-4.

69 Nicolas Coulombel and Fabien Leurent, «Les ménages arbitrent-ils entre coût du logement et coût du transport: une réponse dans le cas francilien», Economie et statistique 457 (2013): 57-75 ; Annarita Polacchini and Jean-Pierre Orfeuil, «Les dépenses des ménages franciliens pour le logement et les transports», Recherche Transports Sécurité 63 (1999): 31-46.

70 Eric Le Breton, Les épreuves de la dispersion. Recherche exploratoire sur les expériences individuelles de la société dispersée, Report, Rapport final pour le Prédit, GO $\mathrm{n}^{\circ} 1$, (Paris: 2004). 
inclusive mobility is to facilitate access to mobility in order to give people access to jobs and resources in general. Conversely, some poor or very vulnerable people are highly mobile, yet at the same time very restricted in their day-to-day travel, with no choice regarding mode of transport, travel times, or physical and financial costs. Yves Jouffe ${ }^{71}$ has studied the "paradoxical mobility" of workers in insecure employment, who develop tactics to get a job, to adapt to the constraints of staggered working hours, and to overcome their lack of a "fixed" place of residence. For their part, Cass, Shove and Urry ${ }^{72}$, drawing on the categories already identified by Church et al..$^{73}$, emphasise that high mobility can be associated with a lack of spatiotemporal availability - in other words the difficulty of balancing schedules with growing numbers of family or work obligations - resulting in low participation in social activities.

This ambivalence in day-to-day mobility, a resource that is essential but sometimes sorely lacking for individuals in situations of insecurity or poverty, reflects both the social role attributed to mobility and the way that improvements in travel conditions affect different social groups unequally in their impact on the spatialization of resources.

As Bacqué and $\mathrm{Fol}^{74}$ note, the ability to be mobile, to move, to adapt, to be flexible, is a prerequisite for all individuals, in particular for working people. At a time when welfare states are in crisis, affecting all European countries, social policies now rely on support for mobility as a condition for returning to work. According to Bacqué and $\mathrm{Fol}^{75}$, by failing to consider the resources of immobility, especially the local roots and social networks developed by the poor ${ }^{76}$, as well as the social costs of mobility, we risk turning mobility from a right into an obligation. For Jamar and Lannoy ${ }^{77}$, it is the problems caused by certain concrete measures purportedly taken on grounds of mobility that reveal the fundamentally political nature of the implementation of a right to mobility. In particular, a right to mobility

71 Yves Jouffe «La paradoxale mobilité des travailleurs précaires : vers de nouvelles inégalités ?», Massot, MH. (coor.), Mobilités et modes de vie métropolitains. Les intelligences du quotidien (Paris: L'Eil d'Or, 2010): 139-153.

${ }^{72}$ Noël Cass, Elisabeth Shove and John Urry, «Social exclusion, mobility and access», Sociological Review 53, 3 (2005): 539-555.

73 Church et al. «Transport and social...

74 Marie-Hélène Bacqué and Sylvie Fol, «L'inégalité face à la mobilité: du constat à l'injonction», Revue Suisse de Sociologie 331 (2007): 89-104.

75 Bacqué and Fol, «L'inégalité...

76 Fol, La mobilité des pauvres...

77 David Jamar and Pierre Lannoy, «Idéaux et troubles d'un droit à la mobilité (ou comment faire de la mobilité un territoire politique», in Mobile/Immobile. Quels choix, quels droits pour 2030, ed. Christophe Gay et al. (Paris : L'Aube, 2011) : 63-73. 
perceived as a factor of social integration raises questions about a form of regulation in which certain types of mobility are defined a priori as deficient (those of the unemployed, the elderly, the poor), and others, conversely, as excessive (that of migrants, asylum seekers, Roms).

Beyond the debate around the ideology of mobility, it has to be recognised that the "social norm" of mobility, that is to say, the "level of mobility practices that society considers 'normal' and that may be demanded of individuals", has grown markedly ${ }^{78}$. By incorporating the increasing mobility capabilities of individuals into their strategies, public and private actors have effectively promoted the increasing spatial dispersal of activities, leading de facto to the marginalisation of the less mobile. For example, competition in the labour market has increased not only because of unemployment, but also because easier mobility has facilitated the expansion of employment catchment areas. More generally, as Orfeuil has noted, "access to a growing number of activities, especially activities involving low-skilled workers, requires a capacity for mobility, which - primarily if not exclusively - takes the form of personal use of a car"79. In other words, individuals, whether their mobility is limited or extensive, have become dependent, in their ways of life, on their access to mobility.

So taking a static or short-term perspective, and implementing a right to mobility for all which aims to find solutions for the deficiency of access to transport of individuals who lack the ability to move, does not settle the longer term issue of the increasing marginalisation of the poor resulting from their dependence on mobility.

\section{From the right to mobility to universal access to the city?}

This finding prompts us to consider the question of inequalities in mobility from another angle, by returning to the issue of inequality of access to resources.

Usually, transport systems do not meet a need to be on the move, but the need to access distant places in order to participate in activities. By making it easier for individuals to travel, transport policies have improved access to resources, while contributing to a growing spatial dispersal of activities that is damaging to people with the least resources, who have no choice in their place of residence, employment or activities.

78 Jean-Pierre Orfeuil, «Des difficultés de mobilité variées qui appellent des réponses personnalisées», in Accès et mobilité. Les nouvelles inégalités, ed. Orfeuil, Jean-Pierre and Ripoll, Fabrice (Gollion: Infolio, 2015): 9-101.

${ }^{79}$ Orfeuil, «Des difficultés..., 43. 
However, access to urban resources is not just a question of transport. Hansen $^{80}$ was already emphasising the difference between mobility, or the ability to move, and accessibility, or "potential of opportunities for interaction". Accessibility is not just about the ease of reaching different opportunities, but varies according to the spatial distribution of those opportunities. It also depends on other things, such as time factors (opening and closing times, individual schedules) and individual characteristics (age, gender, monetary resources, social or ethnic origin).

Numerous studies since the 1990s have been dedicated to the measurement of inequalities in access to urban resources, highlighting the diversity and richness of the concept of accessibility, and its operational applications (for comprehensive reviews, see in particular van Wee and Geurs $^{81}$, Farrington and Farrington ${ }^{82}$, Geurs and van Wee ${ }^{83}$ ). According to Farrington and Farrington ${ }^{84}$, improving accessibility is one of the conditions for achieving an inclusive society, which is itself a condition for social justice: "A just society is one that inter alia grants the opportunity of participation in society to all of its members, and a society will certainly be unjust if it does not grant this opportunity to all its members. Thus, a just society is inter alia a socially inclusive one, and a society is unjust if it is a socially exclusive one." Because it refers to a potential, not an actual practice, the concept of accessibility appears a less ambiguous way to measure inequalities in access to resources.

Moreover, the notion of accessibility allows a wide-ranging exploration of the impacts of policies for transport, urban planning, housing or social inclusion. In particular, by introducing accessibility indicators into the methods used to assess transport projects, it is possible to identify potential winners and losers and to think about how the benefits of these new infrastructures can be distributed more equitably, without exacerbating urban sprawl ${ }^{85}$. A more coordinated implementation of policy in the fields

80 Walter G. Hansen, «How accessibility shapes land use», Journal of American Institute of Planners 25, 1 (1959): 73-76.

${ }^{81}$ Bert Van Wee and Karst T Geurs, «Discussing equity and social exclusion in accessibility evaluations» EJTIR, 11, 4 (2011): 350-367.

82 John Farrington and Conor Farrington, «Rural accessibility, social inclusion and social justice: towards conceptualization», Journal of Transport Geography 13 (2005): 1-12.

${ }^{83}$ Karst T. Geurs and Bert Van Wee, «Accessibility evaluation of land-use and transport strategies: Review and research directions», Journal of Transport Geography 12 (2004): 127140 .

${ }^{84}$ Farrington and Farrington, «Rural accessibility... 5.

85 Karel Martens «Basing transport planning on principles of social justice», Berkeley Planning Journal 19(1), (2006): 1-17 ; Sylvie Fol and Caroline Gallez, «Social inequalities in urban access: better ways of assessing transport improvements», in Getting There/ Being There: Financing Enhanced Urban Access in the 21st Century City, ed. Sclar, 
of transport, urban development and housing also seems essential, and is already the subject of a number of innovations in the sphere of operational planning, as illustrated by Accessibility Planning in the $\mathrm{UK}^{86}$ or the contractual coordination tools being implemented around railway projects in France ${ }^{87}$.

\section{Conclusion}

In addressing together the way social inequalities in (relation to) mobility are taken into account in public policies and the findings from the measurement of actual inequalities in mobility and access to transport in European countries, we are able to show a number of results.

Politically, the concepts of "inclusive mobility" or mobility in the service of an "inclusive society" refer to a specific sense of the challenges of transport and travel. At both European and national level, these notions bear the imprint of the dominant positive ideology associated with mobility, understood as a condition in which all individuals can participate in the society in which they live, and in particular are able to find employment. But mobility is a particularly problematic issue when it comes to expressing a universal right. The idea of need usually associated with daily trips (which legitimises government intervention in transport) is open to challenge in the light of the political and economic factors that - to a greater or lesser degree - generate or structure it, as Jamar and Lannoy ${ }^{88}$ suggest with respect to the "polymorphous and mass" character of contemporary movement.

Beyond this radical critique and on a more pragmatic level, the concept of inclusive mobility tackles only part of the problem of social inequality in (response to) mobility: that of the lack of access to transport modes. It brings into question the consequences of a process of increasing dependence on mobility, which is particularly detrimental to the most economically vulnerable.

E., Lonnröth and M., Wolmar, C. (New York: Routledge, 2014): 46-86 ; V. Dimitra Pyrialakou, Konstantina Gkritza and Jon D Fricker, «Accessibility, mobility and realized travel behaviour: Assessing transport disadvantage from a policy perspective», Journal of Transport Geography 51 (2016): 252-269.

86 Halden, «The use and abuse of accessibility....

87 Juliette Maulat and Aurélie Krauss, "Using contrats d'axe to coordinate regional rail transport, stations and urban development: from concept to practice", Town Planning Review 85, 2 (2014): 287-311.

88 Jamar and Lannoy, "Idéaux et troubles... 
This bias seems to be partially resolved by shifting from the concept of inclusive mobility to that of inclusive accessibility, which underpins a more comprehensive and cross-cutting vision of the problem of access to resources ${ }^{89}$. In a case, improving access to resources depends crucially on local conditions ${ }^{90}$. The role of residents and city users in planning access to resources is absolutely essential both to an understanding of the needs of people and to their real sense of ownership of this potential.

\section{Bibliography}

Bacqué, Marie-Hélène and Fol Sylvie. «L'inégalité face à la mobilité : du constat à l'injonction ». Revue Suisse de Sociologie 33, 1 (2007) : 89-104.

Banister, David. «Reducing the Need to Travel through Planning». Town Planning Review 65, 4 (1994): 349-354.

Bhat, Chandra R., Sudeshna Sen and Naveen Eluru. «The impact of demographics, built environment attributes, vehicle characteristics, and gasoline prices on household vehicle holdings and use». Transportation Research Part B 43 (2009): 1-18.

Bourdages, Jade and Eric Champagne. "Penser la mobilité durable au-delà de la planification traditionnelle du transport ». VertigO - la revue en ligne des sciences de l'environnement 11713 (2012) : http://vertigo.revues.org/11713

Cass, Noël, Elisabeth Shove and John Urry. «Social exclusion, mobility and access». Sociological Review 53, 3 (2005) : 539-555.

Castel, Robert. Les métamorphoses de la question sociale. Une chronique du salariat. Paris : Gallimard, 1999.

Caubel, David. Politique de transports et accès à la ville pour tous? Une méthode d'évaluation appliquée à l'agglomération lyonnaise, Thèse de doctorat, Lyon, Université Lumière-Lyon II, Economie des transports, 2006.

Cavailhès, Jean and Harris Selod. "Ségrégation sociale et périurbanisation ». Inra Sciences Sociales 1-2 (2003) : 1-4.

Church, Andrew, Marti Frost and Karen Sullivan. «Transport and social exclusion in London». Transport Policy 7 (2000) : 195-205.

Clifton, Kelly J. «Mobility Strategies and Food Shopping for Low-Income Families». Journal of Planning Education and Research 23 (2004): 402-413.

Collet, Roger, Jean-Loup Madre and Laurent Hivert. « Diffusion de l'automobile en France : vers quels plafonds pour la motorisation et l'usage ? ». Economie et statistiques 457-458 (2013) : 1-17.

Coulombel, Nicolas, and Fabien Leurent. « Les ménages arbitrent-ils entre coût du logement et coût du transport : une réponse dans le cas francilien ». Economie et statistique 457 (2013) : 57-75.

89 Fol and Gallez, "Social inequalities...

90 Jeffrey Gutman and Nirav Patel, Is better access key to inclusive cities? Making urban areas accessible, (Washington: Brookings, 2016). 
Cresswell, Tim. «The Right to Mobility: The Production of Mobility in the Courtroom». Antipodes 38,4 (2006): 735-754.

Dargay, Joyce and Mark Hanly. «Volatility of car ownership, commuting mode and time in the UK ». Transportation Research Part A 41 (2007) : 934-948.

Diaz Olvera, Lourdes, Dominique Mignot and Christelle Paulo. « Daily mobility and inequality: the situation of the poor». Built Environment 30 (2004) : 153-160.

Didier, Emmanuel. « De 1"“exclusion” à l'exclusion ». Politix 9, 34 (1996) : 5-27.

Dupuy, Gabriel. La dépendance automobile. Symptômes, analyses, diagnostic, traitement. Paris : Anthropos, 1999.

European Commission. White paper on transport. Roadmap to a single European transport area. Luxembourg : Publications Office of the European Union, 2011.

Farrington, John and Conor Farrington. « Rural accessibility, social inclusion and social justice: towards conceptualization ». Journal of Transport Geography 13 (2005) : 1-12.

Féré, Cécile, Concilier accès à la mobilité et mobilité durable. La prise en compte des inégalités d'accès à la mobilité dans les politiques urbaines de l'agglomération lyonnaise, Lyon, Université de Lyon II, Thèse de doctorat en géographie, aménagement et urbanisme, 2011.

Fol, Sylvie, La mobilité des pauvres, Belin, Paris, 2009.

Sylvie Fol and Caroline Gallez. "Social inequalities in urban access. Better ways of assessing transport improvements ». In Urban Access for the 21st Century. Finance and governance models for transport infrastructure, ed. Elliott D. Sclar, Mans Lönnroth and Christian Wolmar, 46-86. London : Routledge, 2014.

Fortier, Anne-Marie. « The Politics of Scaling, Timing and Embodying: Rethinking the 'New Europe' ». Mobilities 1, 3 (2006) : 313-331.

Gaffron, Philine, Julian Hine and Falconer Mitchell. The role of transport on social exclusion in urban Scotland. Literature Review, Transport Research Unit, Edinburgh Napier University, 2001.

Gallez, Caroline, La mobilité quotidienne en politique. Des manières de voir et d'agir, Marne-la-Vallée : Université Paris-Est, Mémoire d'habilitation à diriger des recherches, 2015.

Geurs, Karst T. and Bert Van Wee. « Accessibility evaluation of land-use and transport strategies: Review and research directions ». Journal of Transport Geography 12 (2004) : 127-140.

Giuliano, Genevieve and Joyce Dargay. «Car ownership, travel and land use: a comparison of the US and Great Britain ». Transportation Research Part A 40 (2006) : 106-124.

Goodwin, Phil, Sharon Hallet, Francesca Kenny and Gordon Stokes, Transport: the new realism, Report 624, Transport Studies Unit, University of Oxford, Oxford, 1991.

Greene, David L., and Michael Wegener. « Sustainable transport ». Journal of Transport Geography 5, 3 (1997) : 177-190.

Grimal, Richard, Roger Collet and Jean-Loup Madre. « Is the Stagnation of Individual Car Travel a General Phenomenon in France? A Time-Series Analysis by Zone of Residence and Standard of Living ». Transport Reviews 33 (2013) : 291-309. 
Gutman Jeffrey and Patel, Nirav, Is better access key to inclusive cities? Making urban areas accessible, Washington : Brookings, 2016.

Halden, Derek. «The use and abuse of accessibility measures in UK passenger transport planning ». Research in Transportation Business and Management 2 (2011) : 12-19.

Hansen, Walter G. « How accessibility shapes land use ». Journal of American Institute of Planners 25, 1 (1959) : 73-76.

Harzo, Christian, Mobilité des populations en difficultés : connaissance des besoins et réponses nouvelles, document de synthèse, Report, DIV et Ministère de l'Emploi et de la Solidarité, Paris, 1998.

Hine, Julian. « Travel demand management and social exclusion ». Mobilities 2, 1 (2007) : 109-120.

Hine, Julian and Md. Kamruzzaman. « Journeys to health services in Great Britain: An analysis of changing travel patterns 1985-2006 », Health and place 18 (2012) : 274-285.

Hivert, Laurent, Le parc automobile des ménages, étude en fin d'année 1999 à partir de la source“ Parc Auto” SOFRES, Report, Arcueil : INRETS, 2001.

Jamar, David and Pierre Lannoy. "Idéaux et troubles d'un droit à la mobilité (ou comment faire de la mobilité un territoire politique ». In Mobile/Immobile. Quels choix, quels droits pour 2030, ed. Christohpe Gay et al., 63-73. Paris : L'Aube,2011.

Jouffe, Yves. «La paradoxale mobilité des travailleurs précaires : vers de nouvelles inégalités ? ». In Mobilités et modes de vie métropolitains. Les intelligences du quotidien, ed. Marie-Hélène Massot, Paris : L'EEil d'Or, 2010 : 139-153.

Kawabata, Mizuki and Qing Shen. « Commuting inequality between cars and public transit: The case of the San Francisco Bay Area, 1990-2000 ». Urban Studies 44 (2007) : 1759-1780.

Langan, Céleste. « Mobility Disability ». Public Culture 13, 3 (2001) : 459-484.

Le Breton, Eric. Bouger pour s'en sortir. Mobilité quotidienne et intégration sociale. Paris : Armand Colin, 2005.

Le Breton, Eric, Les épreuves de la dispersion. Recherche exploratoire sur les expériences individuelles de la société dispersée. Report, Rapport final pour le Prédit, GO n 1 , Paris, 2004.

Lucas, Karen. «Providing transport for social inclusion within a framework for environmental justice in the UK ». Transportation Research Part A 40 (2006) : 801-809.

Maitre, Bertrand, Brian Nolan and Christopher T. Whelan. «L'indicateur EU2020 de suivi de la pauvreté et de l'exclusion : une analyse critique ». Economie et Statistique 469-470 (2014) 147-167.

Marlier, Eric, Cantillon, Béa, Nolan, Brian, Van den Bosch, Karel, Van Rie, Tim, «Developing and learning from measures of social inclusion in the European Union ». In Counting the poor: New thinking about European poverty measures and lessons for the United States, ed. Besharov, D.J. and Couch, K.A., 299-338. Oxford : Oxford University Press, 2012.

Martens, Karel. «Basing transport planning on principles of social justice ». Berkeley Planning Journal 19, 1 (2006) : 1-17. 
Martens, Karel. « Role of the bicycle in the limitation of transport poverty in the Netherlands ». Journal of the Transportation Research Board 2387 (2013) : 20-25.

Maulat, Juliette and Aurélie Krauss. «Using contrats d'axe to coordinate regional rail transport, stations and urban development: from concept to practice ». Town Planning Review 85, 2 (2014) : 287-311.

Mignot, Dominique. Mobilité et grande pauvreté, Rapport final pour le ministère de l'Equipement, des Transports et du Logement et pour l'Union des Transporteurs Publics. Paris, 2011.

Mohl, Raymond A. «Stop the road: Freeway revolts in American cities ». Journal of Urban History 30, 5 (2004) : 674-706.

Motte-Baumvol, Benjamin. «L'accès des ménages aux services dans l'espace périurbain francilien ». Strates 14 (2008) : 149-164.

Motte-Baumvol, Benjamin, Marie-Hélène Massot and Andrew M. Byrd. « Escaping Car Dependence in the Outer Suburbs of Paris ». Urban Studies 47 (2010) : 604-619.

Orfeuil, Jean-Pierre, « Des difficultés de mobilité variées qui appellent des réponses personnalisées ». In Accès et mobilité. Les nouvelles inégalités, ed. Jean-Pierre Orfeuil y Ripoll, Fabrice,9-101. Gollion : Infolio, 2015.

Orfeuil, Jean-Pierre. Transports, pauvreté, exclusions. Pouvoir bouger pour s'en sortir. Paris : Editions de l'Aube, 2004.

Paugam, Serge. L'exclusion. L'état des savoirs. La Découverte, Paris, 1996.

Polacchini, Annarita and Jean-Pierre Orfeuil. «Les dépenses des ménages franciliens pour le logement et les transports ». Recherche Transports Sécurité 63 (1999) : 31-46.

Pyrialakou, V. Dimitra, Konstantina Gkritza and Jon D. Fricker. « Accessibility, mobility and realized travel behaviour: Assessing transport disadvantage from a policy perspective ». Journal of Transport Geography 51 (2016) : 252-269.

Rémy, Jean. "Mobilités et ancrages : vers une autre définition de la ville ». In Mobilités et ancrages : vers un nouveau mode de spatialisation ?, ed. Hirchhorn, M. and Berthelot, J.-M., 135-153. Paris : L'Harmattan, 1996.

Roncayolo, Marcel. La ville et ses territoires. Paris : Gallimard, 1990.

Rosanvallon, Pierre. La nouvelle question sociale. Repenser l'Etat providence. Paris : Seuil, 1995.

Sanchez, Thomas W. «Poverty, policy, and public transportation ». Transportation Research A 42 (2008) : 833-841.

Scheiner, Joachim. «Social inequalities in travel behaviour: trip distances in the context of residential self-selection and lifestyles ». Journal of Transport Geography 18 (2010) : 679-690.

Social Exclusion Unit (SEU). Making the Connections: Final report on Transport and social exclusion, Report, London : SEU, 2003.

Syed, Samina T., Ben S. Gerber, and Lisa K. Sharp. « Traveling towards disease: Transportation barriers to health care access ». Journal of community health 38 (2013) : 976-993.

Taylor, J., Barnard, M., Neil, H. and Creegan, C., The travel choices and needs of low income households-the role of the car, London : National Centre For Social Research, 2008. 
Ureta, Sebastiàn. « To Move or Not to Move? Social Exclusion, Accessibility and Daily Mobility among the Low-income Population in Santiago de Chile ». Mobilities 3 (2008) : 269-289.

Urry, John. Sociology Beyond Societies. London : Routledge, 2000.

Urry, John. Mobilities. Cambridge : Polity Press, 2007.

Van Wee, Bert and Karst T. Geurs. " Discussing equity and social exclusion in accessibility evaluations ». EJTIR, 11, 4 (2011) : 350-367.

Wixey, Sarah, Peter Jones, Karen Lucas and Madelein Aldridge. Measuring accessibility as experienced by different socially disadvantaged groups. London : Transport Studies Group, University of Westminster, 2005. 


\section{Derechos de autor}

Los derechos de autor (para la distribución, comunicación pública, reproducción e inclusión en bases de datos de indexación y repositorios institucionales) de esta publicación (Cuadernos Europeos de Deusto, CED) pertenecen a la editorial Universidad de Deusto. El acceso al contenido digital de cualquier número de Cuadernos Europeos de Deusto es gratuito, transcurridos 6 meses desde su publicación. Los trabajos podrán descargarse, copiar y difundir en cualquier medio sin fines comerciales y según lo previsto por la ley; sin la previa autorización de la Editorial (Universidad de Deusto) o el autor. Así mismo, los trabajos editados en CED pueden ser publicados con posterioridad en otros medios o revistas, siempre que el autor indique con claridad y en la primera nota a pie de página que el trabajo se publicó por primera vez en $C E D$, con indicación del número, año, páginas y DOI (si procede). Cualquier otro uso de su contenido en cualquier medio o formato, ahora conocido o desarrollado en el futuro, requiere el permiso previo por escrito del titular de los derechos de autor.

\section{Copyright}

Copyright (for distribution, public communication, reproduction and inclusion in indexation databases and institutional repositories) of this publication (Cuadernos Europeos de Deusto, CED) belongs to the publisher University of Deusto. Access to the digital content of any Issue of Cuadernos Europeos de Deusto is free only six months after its publication. The content can be accessed, downloaded, copies, and distributed freely in any medium only for non-commercial purposes and in accordance with any applicable copyright legislation, without prior permission from the copyright holder (University of Deusto) or the author. Thus, the content of $C E D$ can be subsequently published in other media or journals, as long as the author clearly indicates in the first footnote that the work was published in $C E D$ for the first time, indicating the Issue number, year, pages, and DOI (if applicable). Any other use of its content in any medium or format, now known or developed in the future, requires prior written permission of the copyright holder. 